\title{
Genetic Basis of Resistance to Systemic Infection by Xanthomonas axonopodis pv. dieffenbachiae in Anthurium
}

\author{
W. Elibox and P. Umaharan
}

Department of Life Sciences, Faculty of Science and Agriculture, The University of the West Indies, St. Augustine Campus, Republic of Trinidad and Tobago.

Accepted for publication 10 November 2007.

\section{ABSTRACT}

Elibox, W., and Umaharan, P. 2008. Genetic basis of resistance to systemic infection by Xanthomonas axonopodis pv. dieffenbachiae in anthurium. Phytopathology 98:421-426.

The genetic basis of systemic resistance to bacterial blight disease (blight) of anthurium (Anthurium andraeanum) caused by Xanthomonas axonopodis pv. dieffenbachiae was investigated in progenies of 53 crosses involving 31 parent cultivars using segregation analysis. Inoculation of parents and progenies was achieved by injecting the petiole base of the most recent fully expanded leaf with $100 \mu$ of $10^{9}$ colony forming units per $\mathrm{ml}$ of the blight pathogen (strain X4gfp) transformed with the green fluorescent protein (GFP) gene. The time to death and the presence or absence of GFP fluorescence on newly emerging leaves was monitored over a period of 30 weeks after inoculation (WAI), on an individual plant basis. The expected resistance to susceptible ratios based on a digenic model involving two dominant genes, designated $\mathrm{A}$ and $\mathrm{B}$, interacting according to a duplicate recessive epistasis model fitted the observed segregation ratios in the crosses. Based on the segregation ratios obtained, the parental cultivars were assigned plausible genotypes. There were significant differences $(P<0.001)$ in time to death following inoculation between the various genotypic designations. Cultivars with genotypes $\mathrm{AABB}, \mathrm{AABb}, \mathrm{AaBB}$, and $\mathrm{AaBb}$ died within $10 \mathrm{WAI}$ and designated as susceptible; AAbb and aaBB died from 18.8 to $25.6 \mathrm{WAI}$ and were designated as moderately resistant; and $\mathrm{Aabb}, \mathrm{aaBb}$, and aabb produced resistant phenotypes. There was also some evidence for dosage effect especially in the highly resistant category. Hence, $(\mathrm{AABb}=\mathrm{AaBB}=$ $\mathrm{AaBb})<(\mathrm{aaBB}=\mathrm{AAbb})<\mathrm{Aabb}=\mathrm{aaBb}=\mathrm{aabb})$. An approach to fixing resistance to blight in anthurium is discussed.

Additional keywords: interallelic interaction, nonadditive effects, oligogenic inheritance.
The bacterial blight disease (blight) of Anthurium andraeanum (Hort.) (18) caused by Xanthomonas axonopodis pv. dieffenbachiae (31), previously known as $X$. campestris pv. dieffenbachiae $(4,24)$ was primarily responsible for the rapid decline in anthurium production in Hawaii during the 1980s $(13,17$, $21,25)$ and the Caribbean during the late 1980s $(10,34)$ and 1990s (8).

The disease has two phases, a foliar and a systemic phase (11). In the foliar phase the pathogen invades the foliage of the plant via hydathodes (29). In susceptible cultivars, the foliar infections can rapidly progress into a systemic phase resulting in plant death. Anthurium cultivars show differential susceptibility to the foliar and systemic phases of blight (11). The symptoms are characterized by water-soaked leaf spots with a dark center surrounded by a yellow halo (26); leaf chlorosis (25); yellowing of older leaves and petioles causing the infected leaves and flowers to break off easily revealing dark brown streaks at their bases (26); and the eventual collapse of the plant. Infections may also advance without visual symptoms (27) until the infected plant collapses and dies (11).

Long-term management of blight requires an integrated approach involving genetic resistance $(19,20)$ along with other supplemental disease management tactics including pathogen exclusion, cultural practices and sanitation (6). The development of anthurium cultivars resistant to blight can reduce the level of capital and management costs associated with the cultural control of the disease, and improve profitability of anthurium cultivation

Corresponding author: P. Umaharan; E-mail address: pumaharan@fsa.uwi.tt

doi:10.1094/PHYTO-98-4-0421

(c) 2008 The American Phytopathological Society in the Caribbean (2) and in other anthurium producing countries where the disease has been reported (1).

A recent review of the status of the disease in Hawaii (1) reported that natural genetic resistance to blight is not present in A. andraeanum (Linden) ex André. A number of screening approaches were developed in the 1990s in Hawaii $(11,12,13)$ and resistance to blight was successfully transferred from $A$. antioquiense to A. andreaanum. The efficiency of such conventional breeding efforts could however, be further improved through a clear understanding of the mechanism of resistance to blight and its genetic basis. One attempt at nonconventional breeding using bioengineering (22) increased tolerance to blight but did not confer resistance.

Recently, a rapid green fluorescent protein (GFP) based screening method for the identification of systemic resistance to blight in anthurium was developed (8). This method has led to the identification of numerous sources of systemic resistance to blight in $A$. andraeanum (Hort.). This method also lends itself for the screening of large segregating populations on an individual plant basis and is hence amenable to genetic studies.

In this study, we describe the genetic basis of systemic resistance to blight in A. andraeanum (Hort.).

\section{MATERIALS AND METHODS}

Anthurium cultivars. Thirty-one A. andraeanum (Hort.) cultivars, 12 belonging to the resistant, four belonging to the moderately resistant and 15 belonging to the susceptible categories (8), at the systemic level, were used in the study. The cultivars originated from a variety of sources including the Netherlands (Anthura, Avo, Florist, Fla, Theo, and Voguls farms), Hawaii, and the Caribbean. These cultivars were planted and maintained in a 
shade house (75\% shade saran; overlaid with clear plastic) on beds of coconut husk at a commercial anthurium farm, Kairi Blooms Ltd., located in Arima, Trinidad.

Hybridization. Fifty-three biparental crosses were generated involving the various categories of resistance/susceptibility according to established methods (14), during the period January to April 2000. All pollinations were conducted in shade houses between 0600 to $1000 \mathrm{~h}$. Each cross was made at least seven times to generate adequate seeds per cross.

Germination and aftercare. After 6 to 7 months, the ripe (yellow) berries each containing one to two green seeds, were collected and squeezed gently to remove the seeds. The seeds were planted in labeled (name, sowing date) seedling trays containing peat moss (Premier Horticulture Ltd., Quebec, G5R6C1, Canada) in a nursery house covered with plastic and saran $(75 \%$ shade) and equipped with a mist irrigation and fertigation system. The nursery was misted daily for $10 \mathrm{~s}$ at 15 -min intervals between 0900 and 1600 h. Six months after germination, the anthurium seedlings were transplanted into labeled $8 \mathrm{~cm}^{2}(8 \mathrm{~cm}$ deep) pots containing peat moss. After one year, seedlings were transplanted into labeled $10.5 \mathrm{~cm}^{2}(12.5-\mathrm{cm}$ deep) pots containing peat moss and allowed to grow for another year before screening. The plants were fertilized $(1.5 \mathrm{~g})$ on a monthly basis with either triple super phosphate (Keisurit, Germany) or 12-11-13 NPK (El Cosechero, Venezuela). The $\mathrm{pH}$ of the growing medium was maintained at 5.5 by continuous monitoring and applying calcium carbonate (Limestone, TRINCARB, Port-of-Spain, Trinidad), as necessary.
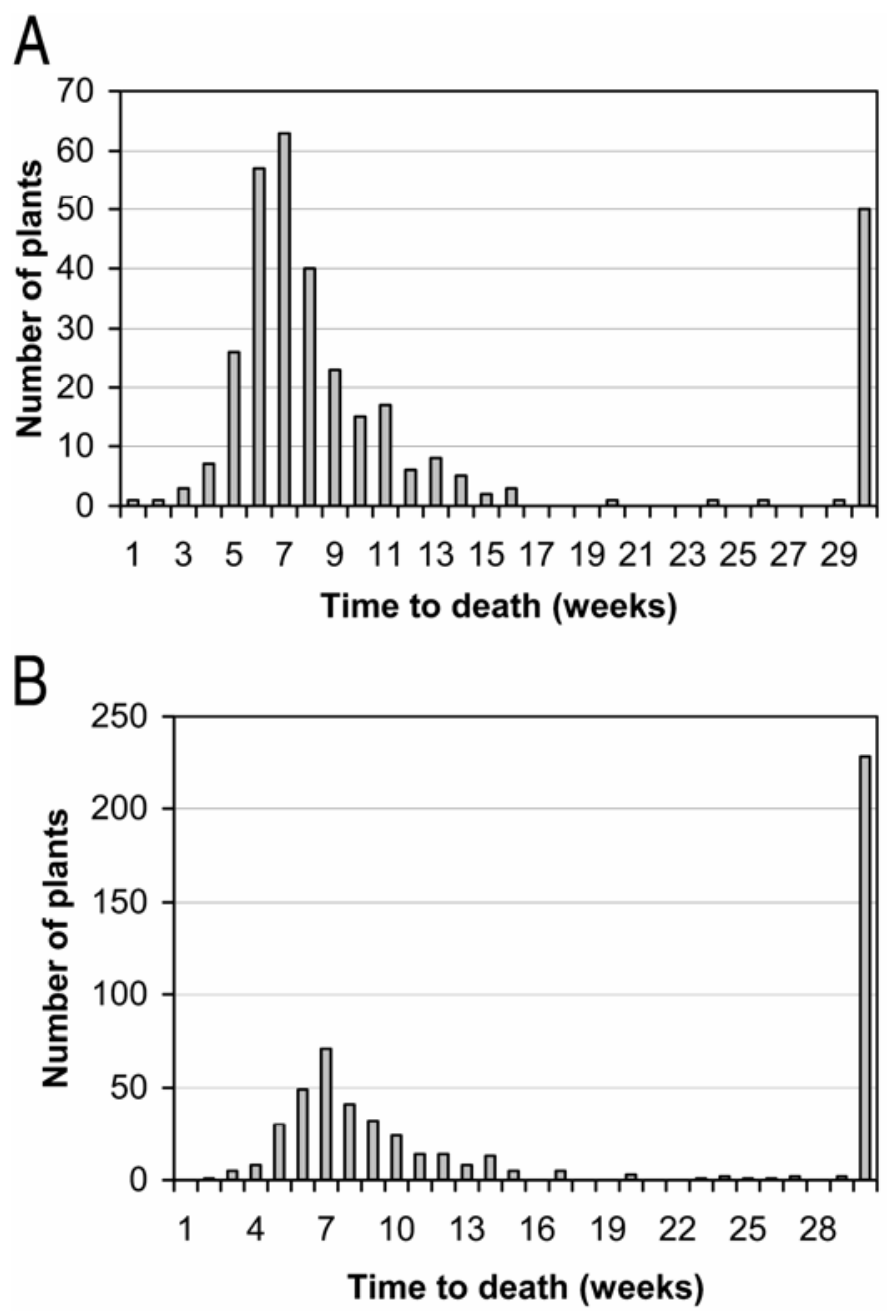

Fig. 1. Frequency distribution of time to death of progenies of $\mathbf{A}$, susceptible $\times$ susceptible Anthurium andraeanum (Hort.) crosses, and B, susceptible $\times$ resistant crosses screened for resistance to bacterial blight disease caused by Xanthomonas axonopodis pv. dieffenbachiae.
The nematicide, Temik (Aldicarb, Shandong, China), was applied once to prevent nematode infestation.

Inoculation. Disease screening was carried out in a screen house, which was located well away from the breeding and nursery houses and drained separately. The segregating progenies ( 2.5 years of age) were individually labeled and transferred to the screen house, and were screened for blight resistance in two batches. Each batch was arranged randomly on concrete benches, regardless of the cross, along with the controls (10 plants each of the parental anthurium cvs. Lydia, Rosa, Cuba, Success, and Midori).

After allowing 6 weeks to acclimatize to the new environment, the plants were inoculated, individually using the optimized method (8). The method involved injecting $100 \mu \mathrm{l}$ of $10^{9}$ colony forming units (CFU) per $\mathrm{ml}$ of inoculum (strain $\mathrm{X} 4 \mathrm{gfp}$ ) into the $2.5-\mathrm{cm}$-long cut petiole stub of the second youngest leaf, and covering the cut surface of the stub overnight, using a $1,000-\mu \mathrm{l}$ pipette tip sealed at the end. The first batch was screened during the period April to November 2003, and the second batch during the period June 2003 to February 2004.

The inoculated plants were watered three times a day with a hose to minimize splashing. The environmental conditions that prevailed during the screening period were monitored using a data logger (Hobo, England).

Data collection. Time taken for each individual plant to collapse/die was measured once a week over a period of 30 weeks after inoculation (WAI). Representative samples of petioles and leaves of each plant were harvested and evaluated for the presence of green fluorescence. The dead plants were removed once a week from the screen house in large garbage bags and burnt. All plants that were symptomless at $30 \mathrm{WAI}$ were tested for the presence of green fluorescence by sampling the petiole bases of leaves. The progeny data were divided into two categories; (a) susceptible, those that died between 0 to $12 \mathrm{WAI}$, and (b) resistant, those that show delayed symptoms/GFP fluorescence or remained free of symptoms/GFP fluorescence (Leica fluorescence microscope, BM IRB model, Germany) at the end of the study period (8).

Data analysis. Segregation analysis was carried out by fitting genetic ratios to the observed ratios of resistance/susceptible progenies for the various crosses. The goodness of fit of the genetic ratios to observed ratios were tested using the chi-square test with Yates' correction. Parental cultivars were assigned genotypes based on the genetic hypothesis and confirmed using other crosses involving the same parents.

Crosses with the same assigned genotype were pooled and a pooled chi-square test $(P \leq 0.05)$ was performed using Yates'

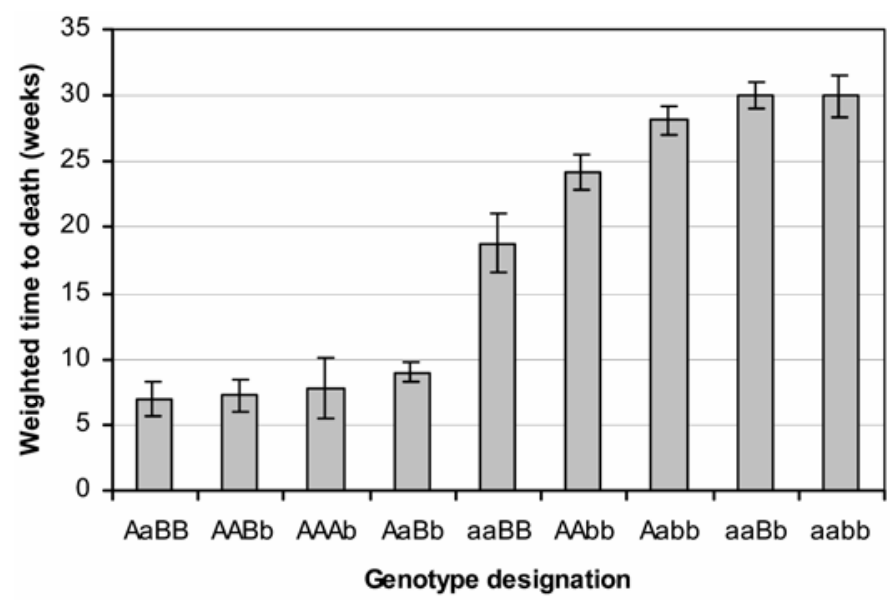

Fig. 2. Mean weighted time to death (weeks) in response to inoculation by Xanthomonas axonopodis pv. dieffenbachiae, as influenced by the genotypic designation for the duplicate recessive bacterial blight resistant genes, A and B for 31 Anthurium andraeanum (Hort.) cultivars. 
correction to determine the significance of fit between the observed ratios and expected ratios. The genotypic designations for the 31 parents with respect to the duplicate recessive blight resistant genes, A and B, determined in this study, were compared to their resistance status (weighted time to death) reported in a previous study (8). A general linear model analysis of variance (ANOVA) (NCSS, 2001, Kaysville, UT) was performed to determine whether there were significant differences between cultivar genotype designations based on weighted time to death. For this purpose, anthurium plants that did not die were given a time to death (dummy value) of 30 weeks.

\section{RESULTS}

Environmental conditions of the screen house. The environmental conditions that prevailed during the screening of progenies over the two batches were very similar. The average relative humidity was $83 \%$; the average temperature was $27.7^{\circ} \mathrm{C}$, and the mean daily light intensity was $57 \mu \mathrm{mol} \mathrm{m} \mathrm{m}^{-2} \mathrm{~s}^{-1}$ during the study period. The comparable results obtained with the control clones over the two inoculation batches suggested that the inoculum potential over the two inoculation trials was similar (data not shown).

Progeny frequency distributions. The progeny frequency distributions for time to symptom development/death were bimodal for all crosses, with some variation around the two modes. Progeny frequency distributions for susceptible $\times$ susceptible crosses and susceptible $\times$ resistant crosses are shown in Figures 1 and 2. Both categories of crosses produced susceptible and resistant cohorts, but at different proportions. All the plants that remained alive at the end of the experimental period were consistently free of GFP fluorescence. Those that remained free of symptoms at the end of the study period had not shown symptoms or died even 2 years after the end of this study.

Segregation analysis. Monogenic models were too simplistic and were not able to explain the segregation ratios in resistant $x$ susceptible data. Further, the appearance of blight resistant genotypes in susceptible $\times$ susceptible crosses (Fig. 1A) and susceptible genotypes in resistant $\times$ resistant crosses (Fig. 1B) suggested the possible influence of modifying factors such as dominance and epistasis in the inheritance.

In some susceptible $\times$ susceptible crosses, the dihybrid ratio, 9:7 susceptible:resistant (S:R) was observed, suggesting duplicate recessive epistasis. The two genes were denoted, ' $A$ ' and ' $B$ '. In the model, 'A' is dominant to ' $a$ ', ' $B$ ' is dominant to ' $b$ ', 'aa' is epistatic to 'B-' and ' $b b$ ' is epistatic to 'A-'. The presence of genotype 'aa' or 'bb', either singly or in combination, produced moderately resistant to resistant phenotypes.

Based on the model, susceptible cultivars were assigned genotypes $\mathrm{AABB}, \mathrm{AaBB}, \mathrm{AABb}$, and $\mathrm{AaBb}$, which is expected to yield $S: R$ ratios of $9: 7,3: 1$, or $1: 0$ in crosses between susceptible cultivars. Fifteen of the sixteen susceptible $\times$ susceptible crosses fitted one of the above three ratios based on $\chi^{2}$ tests (Table 1). Putative genotypes were assigned to the susceptible cultivars and were tested in all crosses of these cultivars with others. Based on designation of genotypes, the moderately resistant cultivars (showing delayed symptoms or death) were assigned AAbb or aaBB, except Honduras which was assigned Aabb. The resistant ones were assigned Aabb, aaBb, or aabb, except Kalapana which was assigned AAbb.

Genotypes assigned to the 31 parent anthurium cultivars from the 53 crosses based on segregation ratios (S:R) supported by chisquare tests with Yate's correction are shown in Tables 1, 2, 3, and 4. Among the resistant $\times$ susceptible crosses, 18 out of the 21 crosses fitted ( $\chi^{2}$ test; $\left.P>0.05\right)$ the expected $\mathrm{S}: \mathrm{R}$ ratios based on the digenic duplicate recessive epistatic model (Table 2). All 11 of the moderately resistant $\times$ susceptible crosses fitted the expected $\mathrm{S}: \mathrm{R}$ ratio $\left(\chi^{2}\right.$ test; $\left.P>0.05\right)$ based on the same genetic model (Table 3), therefore confirming the genotype designations. All of the five resistant $\times$ resistant crosses closely fitted the expected ratios based on the assigned genotypes and were supported by $\chi^{2}$ tests (Table 4). Overall, even in the cases where the $\chi^{2}$ values did not quite support the $S: R$ ratio, the ratios presented were the most plausible based on a digenic model; all the other possible ratios produced much higher $\chi^{2}$ values.

When crosses with the same genotypes were grouped and the chi-square test performed (Table 5), the fit was as good as or better than for single crosses. These together confirmed the digenic model with duplicate recessive epistasis.

Magnitude of dosage effect of recessive alleles. An ANOVA showed that there were significant differences $(P<0.001)$ between the genotypic designations (blight resistant genes A and B) of the 31 parents for weighted time to death. Tukey-Kramer multiple comparison test placed the genotypes in one of three categories. The genotypes designated as $\mathrm{AABb}, \mathrm{AaBB}$, and $\mathrm{AaBb}$ (susceptible cultivars) were not significantly different from each other; those designated as aaBB and AAbb (moderately resistant cultivars) were not significantly different from each other; and those designated as Aabb, aaBb, and aabb (resistant cultivars) were not significantly different from each other. None of the susceptible genotypes were designated AABB.

TABLE 1. Goodness of fit tests (chi-squared test) for expected ratios (and plausible genotypes) based on the digenic duplicate recessive epistatic model versus observed ratios of resistance:susceptible cohorts of progenies of 16 susceptible $\times$ susceptible crosses of Anthurium andraeanum (Hort.) screened for resistance to Xanthomonas axonopodis pv. dieffenbachiae

\begin{tabular}{|c|c|c|c|c|c|c|c|c|}
\hline \multirow[b]{2}{*}{ Female } & \multirow[b]{2}{*}{ Genotype } & \multirow[b]{2}{*}{ Male } & \multirow[b]{2}{*}{ Genotype } & \multirow[b]{2}{*}{ No. of plants } & \multicolumn{2}{|c|}{ Ratios } & \multirow[b]{2}{*}{$\chi^{2}$} & \multirow[b]{2}{*}{ Probability } \\
\hline & & & & & Observed $\mathrm{S}: \mathrm{R}^{\mathrm{a}}$ & Fitted S:R & & \\
\hline Alexis & $\mathrm{AABb}$ & Cumbia & $\mathrm{AaBb}$ & 107 & $74: 33$ & $3: 1$ & 1.648 & $>0.10$ \\
\hline Champagne & $\mathrm{AaBb}$ & Hawaii & $\mathrm{AABb}$ & 68 & $49: 19$ & $3: 1$ & 0.176 & $>0.50$ \\
\hline Champagne & $\mathrm{AaBb}$ & Lydia & $\mathrm{AaBB}$ & 29 & $20: 9$ & $3: 1$ & 0.288 & $>0.50$ \\
\hline Champagne & $\mathrm{AaBb}$ & Pierrot & $\mathrm{AaBb}$ & 122 & $76: 46$ & $9: 7$ & 1.575 & $>0.20$ \\
\hline Champagne & $\mathrm{AaBb}$ & Gloria & $\mathrm{AABb}$ & 30 & $25: 5$ & $3: 1$ & 0.711 & $>0.30$ \\
\hline Fantasia & $\mathrm{AABb}$ & Hawaii & $\mathrm{AABb}$ & 49 & $31: 18$ & $3: 1$ & 3.000 & $>0.05$ \\
\hline Gloria & $\mathrm{AABb}$ & Pierrot & $\mathrm{AaBb}$ & 126 & $88: 38$ & $3: 1$ & 1.524 & $>0.20$ \\
\hline Laguna & $\mathrm{AaBb}$ & $\mathrm{LMR}^{\mathrm{b}}$ & $\mathrm{AaBb}$ & 36 & $13: 23(?)$ & $9: 7$ & 5.143 & $<0.05$ \\
\hline Linda & $\mathrm{AaBB}$ & Midori & $\mathrm{AaBb}$ & 64 & $53: 11$ & $3: 1$ & 1.688 & $>0.10$ \\
\hline Pierrot & $\mathrm{AaBb}$ & Cuba & $\mathrm{AaBB}$ & 36 & $25: 11$ & $3: 1$ & 0.333 & $>0.50$ \\
\hline Pierrot & $\mathrm{AaBb}$ & Midori & $\mathrm{AaBb}$ & 35 & $16: 19$ & $9: 7$ & 1.182 & $>0.25$ \\
\hline Rosa & $\mathrm{AaBb}$ & LMR & $\mathrm{AaBb}$ & 24 & $13: 11$ & $9: 7$ & 0.000 & 1.00 \\
\hline Rosa & $\mathrm{AaBb}$ & Lydia & $\mathrm{AaBB}$ & 20 & $15: 5$ & $3: 1$ & 0.000 & 1.00 \\
\hline Champagne & $\mathrm{AaBb}$ & Victoria & $\mathrm{AaBb}$ & 60 & $32: 28$ & $9: 7$ & 0.106 & $>0.70$ \\
\hline Laguna & $\mathrm{AaBb}$ & Victoria & $\mathrm{AaBb}$ & 45 & $29: 16$ & $9: 7$ & 0.919 & $>0.30$ \\
\hline Pierrot & $\mathrm{AaBb}$ & Victoria & $\mathrm{AaBb}$ & 26 & $13: 13$ & $9: 7$ & 0.199 & $>0.50$ \\
\hline
\end{tabular}

a Susceptible:resistant to bacterial blight disease.

b Local Mina Red. 
It can be noticed from Figure 2 that cultivars with the genotype designations, AaBB (three cultivars), AABb (four cultivars), and $\mathrm{AaBb}$ (eight cultivars) all died within 10 WAI (susceptible category). The weighted time to death for the single cultivar designated as 'aaBB' was 18.8 weeks, whereas those for cultivars designated as AAbb (three cultivars) ranged from 18.8 weeks to 25.6 weeks with the exception of Kalapana, which was 28.4 weeks. Cultivars with at least three recessive alleles fell into the highly resistant category. Cultivars designated as aaBb (five cultivars) or aabb (two cultivars) did not become infected at the end of the experiment or two years thereafter. In the highly resistant category of genotypes that had a genotypic designation 'Aabb' (five cultivars), only a few plants became infected systemically, and even those showed a much delayed decline. These results show that a digenic model with duplicate recessive epistasis (with dosage effects) can explain resistance to systemic infection by $X$. axonopodis pv. dieffenbachiae in anthurium.

\section{DISCUSSION}

Anthurium cultivars have been shown to display differential susceptibility to foliar and systemic phases of bacterial blight infection (11). Resistance to both phases of infection will be required to reduce the damaging effects of the pathogen. In this study, we focused mainly on host resistance at the systemic phase of the infection.

Understanding the genetic basis of resistance to blight in anthurium is important both for selecting parents for breeding and for designing an efficient breeding programme. This study, using 3,444 progenies from 53 crosses involving 31 parental cultivars, showed that resistance to blight in anthurium is determined by a digenic model with dominance (in the direction of susceptibility) and duplicate recessive epistasis. If the two genes are labeled ' $\mathrm{A}$ ' and ' $\mathrm{B}$ ', then either gene in the recessive form will impart moderate resistance/resistance to blight. By fitting ratios for the progenies

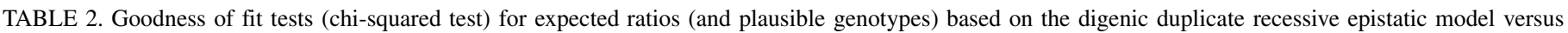

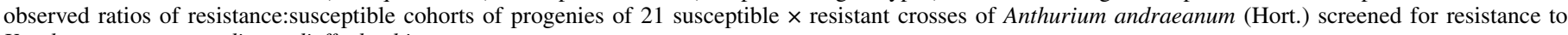
Xanthomonas axonopodis pv. dieffenbachiae

\begin{tabular}{|c|c|c|c|c|c|c|c|c|}
\hline \multirow[b]{2}{*}{ Female } & \multirow[b]{2}{*}{ Genotype } & \multirow[b]{2}{*}{ Male } & \multirow[b]{2}{*}{ Genotype } & \multirow[b]{2}{*}{ No. of plants } & \multicolumn{2}{|c|}{ Ratios } & \multirow[b]{2}{*}{$\chi^{2}$} & \multirow[b]{2}{*}{ Probability } \\
\hline & & & & & Observed S:R ${ }^{\mathrm{a}}$ & Fitted S:R & & \\
\hline Acropolis $(r)^{b}$ & Aabb & Gloria & $\mathrm{AABb}$ & 59 & $23: 36$ & $1: 1$ & 2.440 & $>0.10$ \\
\hline Acropolis (r) & Aabb & Hawaii & $\mathrm{AABb}$ & 113 & $47: 66$ & $1: 1$ & 2.868 & $>0.05$ \\
\hline Acropolis (r) & Aabb & Victoria & $\mathrm{AaBb}$ & 104 & $40: 64$ & $3: 5$ & 0.010 & $>0.90$ \\
\hline Bianco (r) & $\mathrm{aaBb}$ & Pierrot & $\mathrm{AaBb}$ & 40 & $14: 26$ & $3: 5$ & 0.027 & $>0.80$ \\
\hline Kalapana (r) & $\mathrm{AAbb}$ & Hawaii & $\mathrm{AABb}$ & 31 & $19: 12$ & $1: 1$ & 1.162 & $>0.25$ \\
\hline Kalapana (r) & $\mathrm{AAbb}$ & $\operatorname{Loc}^{M} \operatorname{Red}^{\mathrm{c}}$ & $\mathrm{AaBb}$ & 30 & $15: 15$ & $1: 1$ & 0.000 & 1.00 \\
\hline $\mathrm{LMW}^{\mathrm{d}}(\mathrm{r})$ & $\mathrm{aaBb}$ & Cuba & $\mathrm{AaBB}$ & 96 & $58: 38$ & $1: 1$ & 3.760 & $>0.05$ \\
\hline Alexis & $\mathrm{AABb}$ & $\operatorname{Loc} \operatorname{Or}^{\mathrm{e}}(\mathrm{r})$ & $\mathrm{aaBb}$ & 94 & $70: 24$ & $3: 1$ & 0.000 & 1.00 \\
\hline Pierrot & $\mathrm{AaBb}$ & Loc Or $(r)$ & $\mathrm{aaBb}$ & 73 & $24: 49$ & $3: 5$ & 0.485 & $>0.30$ \\
\hline Cuba & $\mathrm{AaBB}$ & Local Pink (r) & $\mathrm{aaBb}$ & 52 & $22: 30$ & $1: 1$ & 0.942 & $>0.30$ \\
\hline Laguna & $\mathrm{AaBb}$ & Local Pink (r) & $\mathrm{aaBb}$ & 124 & $52: 72$ & $3: 5$ & 0.861 & $>0.30$ \\
\hline Lydia & $\mathrm{AaBB}$ & Local Pink (r) & $\mathrm{aaBb}$ & 52 & $20: 32$ & $1: 1$ & 2.326 & $>0.10$ \\
\hline Rosa & $\mathrm{AaBb}$ & Local Pink (r) & $\mathrm{aaBb}$ & 28 & $14: 14(?)$ & $3: 5$ & 1.371 & $>0.20$ \\
\hline Mirjam (r) & Aabb & Gloria & $\mathrm{AABb}$ & 65 & $25: 40$ & $1: 1$ & 3.015 & $>0.05$ \\
\hline Champagne & $\mathrm{AaBb}$ & Venus (r) & Aabb & 95 & $22: 73$ & $3: 5$ & 7.743 & $<0.05$ \\
\hline Fantasia & $\mathrm{AABb}$ & Venus (r) & Aabb & 51 & $25: 26$ & $1: 1$ & 0.000 & 1.00 \\
\hline Gloria & $\mathrm{AABb}$ & Venus (r) & Aabb & 71 & $51: 20$ & $1: 1$ & 12.676 & $<0.05$ \\
\hline Midori & $\mathrm{AaBb}$ & Venus (r) & Aabb & 32 & $9: 23$ & $3: 5$ & 0.834 & $>0.30$ \\
\hline Pierrot & $\mathrm{AaBb}$ & Venus (r) & Aabb & 60 & $27: 33$ & $3: 5$ & 1.138 & $>0.25$ \\
\hline Midori & $\mathrm{AaBb}$ & Sweety (r) & aabb & 53 & $8: 45$ & $1: 3$ & 2.271 & $>0.10$ \\
\hline Senator (r) & Aabb & Hawaii & $\mathrm{AABb}$ & 135 & $54: 81$ & $1: 1$ & 5.007 & $<0.05$ \\
\hline
\end{tabular}

a Susceptible:resistant to bacterial blight disease.

b Resistant to bacterial blight disease.

c Local Mina Red.

d Local Mina White.

e Local Orange.

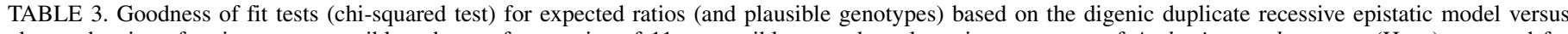

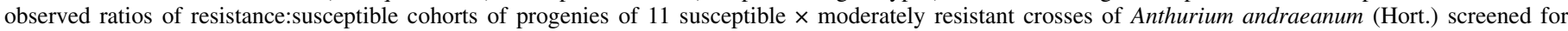
resistance to Xanthomonas axonopodis pv. dieffenbachiae

\begin{tabular}{|c|c|c|c|c|c|c|c|c|}
\hline \multirow[b]{2}{*}{ Female } & \multirow[b]{2}{*}{ Genotype } & \multirow[b]{2}{*}{ Male } & \multirow[b]{2}{*}{ Genotype } & \multirow[b]{2}{*}{ No. of plants } & \multicolumn{2}{|c|}{ Ratios } & \multirow[b]{2}{*}{ Probability } & \multirow[b]{2}{*}{$\chi^{2}$} \\
\hline & & & & & Observed S:R & Fitted S:R & & \\
\hline Alexis & $\mathrm{AABb}$ & Sonate (mr) & $\mathrm{AAbb}$ & 28 & $13: 15$ & $1: 1$ & 0.036 & $>0.80$ \\
\hline Champagne & $\mathrm{AaBb}$ & Honduras (mr) & Aabb & 176 & $63: 113$ & $3: 5$ & 0.152 & $>0.50$ \\
\hline Champagne & $\mathrm{AaBb}$ & Sonate $(\mathrm{mr})$ & AAbb & 37 & $16: 21$ & $1: 1$ & 0.432 & $>0.50$ \\
\hline Laguna & $\mathrm{AaBb}$ & Sonate (mr) & $\mathrm{AAbb}$ & 62 & $25: 37$ & $1: 1$ & 1.952 & $>0.10$ \\
\hline Champagne & $\mathrm{AaBb}$ & Success (mr) & $\mathrm{aaBB}$ & 23 & $11: 12$ & $1: 1$ & 0.000 & 1.00 \\
\hline Cuba & $\mathrm{AaBB}$ & Success (mr) & $\mathrm{aaBB}$ & 50 & $30: 20$ & $1: 1$ & 1.620 & $>0.20$ \\
\hline Gloria & $\mathrm{AABb}$ & Honduras (mr) & Aabb & 66 & $39: 27$ & $1: 1$ & 1.834 & $>0.10$ \\
\hline Honduras $(\mathrm{mr})^{\mathrm{b}}$ & Aabb & Loc M Red ${ }^{c}$ & $\mathrm{AaBb}$ & 92 & $36: 56$ & $3: 5$ & 0.046 & $>0.80$ \\
\hline Honduras (mr) & Aabb & Cuba & $\mathrm{AaBB}$ & 39 & $27: 12$ & $3: 1$ & 0.419 & $>0.50$ \\
\hline Honduras (mr) & Aabb & Victoria & $\mathrm{AaBb}$ & 45 & $18: 27$ & $3: 5$ & 0.037 & $>0.80$ \\
\hline Loc Wh Pink $^{\mathrm{d}}(\mathrm{mr})$ & $\mathrm{AAbb}$ & Pierrot & $\mathrm{AaBb}$ & 135 & $76: 59$ & $1: 1$ & 1.896 & $>0.10$ \\
\hline
\end{tabular}

a Susceptible:resistant to bacterial blight disease.

${ }^{b}$ Moderately resistant to bacterial blight disease.

c Local Mina Red.

${ }^{\mathrm{d}}$ Local whitish Pink. 
of the crosses, it was possible to assign genotypes for all the parents. All possible genotypes were represented within the parental population used in crosses, except 'AABB'. It is possible that cultivars with the genotype 'AABB' were extremely susceptible to blight and may not have survived in the farm.

Similarly, oligogenic inheritance has been reported for resistance to a number of diseases caused by pathovars of $X$. campestris, which are related to $X$. axonopodis pathovars. For instance, resistance to $X$. campestris pv. campestris in cabbage was reported to be controlled by one dominant gene $(15,16,32)$, one or more dominant genes (3), or a recessive gene, influenced by one recessive and one dominant modifying gene (7,33). Similarly, resistance to $X$. campestris pv. oryzae in rice has been shown to be determined by two dominant genes $(5,30)$, or by one dominant gene as observed in some cultivars $(9,28)$. Resistance to bacterial leaf pustule in soybean caused by the closely related $X$. axonopodis pv. glycines was found to be determined by two genes interacting in a duplicate recessive epistasis manner (23).

When the genotypic designation of the parents (blight resistant genes, A and B) were compared with their level of resistance and susceptibility previously reported (8), there was clear evidence suggesting a dosage-effect of recessive resistant genes. For instance, the level of resistance (indicated by the weighted length of time taken to death) in genotypes with at least three recessive alleles (mean 29.3 WAI) was higher and significantly different from those with two recessive alleles at the same locus (mean 22.9 WAI), and those with four recessive alleles did not die at the end of the experiment or thereafter, nor did they show evidence of GFP fluorescence at the end of the experiment. Even in those genotypes with three recessive alleles GFP fluorescence and plant death was seen in only a few of the plants inoculated (8). It is possible that the systemic symptoms may have been masked in genotypes with three recessive alleles and one dominant allele. Although not significant, even within the susceptible category, genotypes with two recessive alleles across two loci ( $\mathrm{AaBb}$ ) had a mean time to death of 9 WAI whereas those with one recessive allele died on average in 7.2 WAI. The dosage effect therefore, could at least partially account for the continuous distributions around the two modes observed in the progeny frequency distributions (Figs. 1 and 2). It can be postulated that $(\mathrm{AABb}=\mathrm{AaBB}=$ $\mathrm{AaBb})<(\mathrm{aaBB}=\mathrm{AAbb})<(\mathrm{Aabb}=\mathrm{a} \mathrm{aBb}=\mathrm{aabb})$.

There was some evidence suggesting a role for minor modifiers in the inheritance of systemic resistance to blight. For instance, cvs. Kalapana and Honduras showed levels of resistance to blight (weighted time to death) (8) that were higher and lower, respectively, than what was expected based on their genotype designations. These suggest that there may be other minor modifier genes that may augment the level of systemic resistance. Modifier genes have been reported to affect resistance to black rot, caused by $X$. campestris pv. campestris, in cabbages $(7,33)$.

A recent review of bacterial blight disease in anthurium contended that natural resistance does not exist in A. andraeanum (Linden) ex André (1). This study supports a previous study that resistance to bacterial blight disease exists in $A$. andraeanum (Hort.) (8) and further describes the genetics of resistance for the first time. In fact, several of the parental cultivars were resistant to blight, and 'Sweety' and 'Ibara' were highly resistant with a possible genotype of 'aabb'. The progenies identified as resistant in this study have remained disease-free for 2 years following the end of the study in a commercial anthurium farm which further shows the validity of this approach.

Based on the results, screening should be continued up to at least 30 weeks through basal petiole sampling, so that genotypes with high levels of resistance can be discerned. Using this approach, one is able to eliminate genotypes with four, three, or two susceptible (dominant) alleles. Genotypes with three recessive alleles could not be separated clearly from those with four alleles, since escapes are possible. Those with one susceptible dominant allele can however be deciphered by performing progeny tests with cultivars with the genotypic designation 'AABb' (Fantasia, Hawaii, and Gloria) or 'AaBB' (Cuba and Linda). The study therefore provides a means of fixing resistance to blight in anthurium.

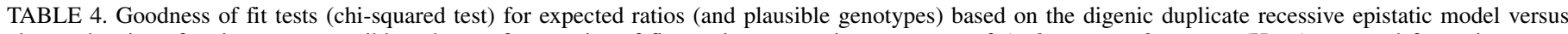

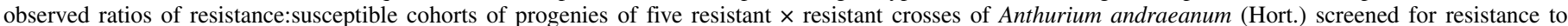
Xanthomonas axonopodis pv. dieffenbachiae

\begin{tabular}{|c|c|c|c|c|c|c|c|c|}
\hline \multirow[b]{2}{*}{ Female } & \multirow[b]{2}{*}{ Genotype } & \multirow[b]{2}{*}{ Male } & \multirow[b]{2}{*}{ Genotype } & \multirow[b]{2}{*}{ No. of plants } & \multicolumn{2}{|c|}{ Ratios } & \multirow[b]{2}{*}{$\chi^{2}$} & \multirow[b]{2}{*}{ Probability } \\
\hline & & & & & Observed $\mathrm{S}: \mathrm{R}^{\mathrm{a}}$ & Fitted S:R & & \\
\hline Mirjam & Aabb & Ibara & Aabb; aabb & 50 & $2: 48$ & $0: 1$ & & \\
\hline Mirjam & Aabb & Kalapana & $\mathrm{AAbb}$ & 60 & $2: 58$ & $0: 1$ & & \\
\hline Mirjam & Aabb & Local & & & & & & \\
\hline Orange & $\mathrm{aaBb}$ & & & 42 & $5: 37$ & $1: 3$ & 3.175 & $>0.05$ \\
\hline Mirjam & Aabb & Tropical & $\mathrm{aaBb}$ & 26 & $7: 19$ & $1: 3$ & 0.000 & 1.00 \\
\hline Local & & & & & & & & \\
\hline Orange & $\mathrm{aaBb}$ & Venus & Aabb & 71 & $14: 57$ & $1: 3$ & 0.793 & $>0.30$ \\
\hline
\end{tabular}

a Susceptible:resistant to bacterial blight disease.

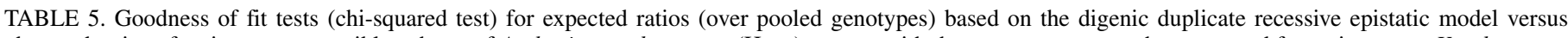

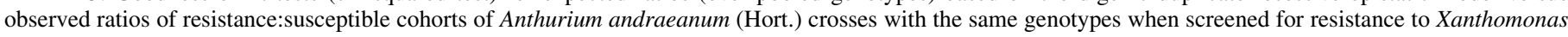
axonopodis pv. dieffenbachiae

\begin{tabular}{|c|c|c|c|c|c|c|c|}
\hline \multirow[b]{2}{*}{ Genotype 1} & \multirow[b]{2}{*}{ Genotype 2} & \multirow[b]{2}{*}{ No. of crosses } & \multirow[b]{2}{*}{ Total number of plants } & \multicolumn{2}{|c|}{ Ratios } & \multirow[b]{2}{*}{$\chi^{2}$} & \multirow[b]{2}{*}{ Probability } \\
\hline & & & & Observed $\mathrm{S}: \mathrm{R}^{\mathrm{a}}$ & Fitted S:R & & \\
\hline $\mathrm{AABb}(\mathrm{s})$ & $\mathrm{AaBb}(\mathrm{s})$ & 4 & 331 & $236: 95$ & $3: 1$ & 2.224 & $>0.10$ \\
\hline $\mathrm{AABb}(\mathrm{s})$ & Aabb (r) & 7 & 560 & $264: 296$ & $1: 1$ & 1.716 & $>0.10$ \\
\hline $\mathrm{AABb}(\mathrm{s})$ & $\mathrm{AAbb}(\mathrm{t})$ & 2 & 59 & $32: 27$ & $1: 1$ & 0.271 & $>0.50$ \\
\hline $\mathrm{AaBb}(\mathrm{s})$ & $\mathrm{AaBb}(\mathrm{s})$ & 7 & 348 & $192: 156$ & $9: 7$ & 0.123 & $>0.70$ \\
\hline $\mathrm{AaBb}(\mathrm{s})$ & AaBB (s) & 4 & 149 & $113: 36$ & $3: 1$ & 0.020 & $>0.80$ \\
\hline $\mathrm{AaBb}(\mathrm{s})$ & Aabb (r) & 7 & 604 & $212: 392$ & $3: 5$ & 0.855 & $>0.30$ \\
\hline $\mathrm{AaBb}(\mathrm{s})$ & $\mathrm{aaBb}(\mathrm{r})$ & 4 & 265 & $104: 161$ & $3: 5$ & 0.274 & $>0.50$ \\
\hline $\mathrm{AaBb}(\mathrm{s})$ & $\mathrm{AAbb}(\mathrm{t})$ & 4 & 264 & $132: 132$ & $1: 1$ & 0.000 & 1.00 \\
\hline $\mathrm{AaBB}(\mathrm{s})$ & $\mathrm{aaBb}(\mathrm{r})$ & 3 & 200 & 100:100 & $1: 1$ & 0.000 & 1.00 \\
\hline $\mathrm{Aabb}(\mathrm{r})$ & $\mathrm{aaBb}(\mathrm{r})$ & 3 & 139 & $26: 113$ & $1: 3$ & 2.612 & $>0.10$ \\
\hline
\end{tabular}

a Susceptible:resistant to bacterial blight disease. 


\section{ACKNOWLEDGMENTS}

This study was supported by a grant from the EUFORUM/ CARIFORUM under the Caribbean Agricultural Research and Technology Fund (CARTF). We thank the management and staff of Kairi Blooms Farm, Arima, Trinidad for providing us with the field resources for this study. We also thank M. Goddard for assistance.

\section{LITERATURE CITED}

1. Alvarez, A. M., Toves, P. J., and Vowell, T. S. 2006. Bacterial blight of anthuriums: Hawaii's experience with a global disease. APSnet Feature. Published online by The American Phytopathological Society, St. Paul, MN.

2. Anaïs, G., Derrasse, A., Prior, P., and Cadic, A. 2000. Breeding anthuriums (Anthurium andraeanum L.) for resistance to bacterial blight caused by Xanthomonas campestris pv. dieffenbachiae. Acta Hortic. 508:135-140.

3. Bain, D. C. 1955. Resistance of cabbage to black rot. Phytopathology 45:35-37.

4. Bradbury, J. F. 1986. Guide to Plant Pathogenic Bacteria. CAB International Mycological Institute, Slough, UK.

5. Chen, J. C. 1990. Genetic analysis of resistance to Philippine races of bacterial blight, Xanthomonas campestris pv. oryzae, in some rice cultivars. Ph.D. thesis. University of the Philippines, Los Banos, Philippines.

6. Deardorff, D. C. 1991. Plant bacterial diseases and their control. Pages 66-69 in: Proc. Hawaii Anthurium Ind. Conf., 4th. A. M. Alvarez, D. C. Deardorff, and K. B. Wadsworth, eds. HITAHR (Hawaii Inst. Trop. Agric. Human Resources) J. Ser. 04.06.91. University of Hawaii, Manoa, Honolulu.

7. Dixon, M. D., and Hunter, J. E. 1987. Inheritance of resistance in cabbage seedlings to black rot. Hortic. Sci. 22:108-109.

8. Elibox, W., and Umaharan, P. 2007. A green fluorescent protein-based screening method for identification of resistance in anthurium to systemic infection by Xanthomonas axonopodis pv. dieffenbachiae. Plant Pathol. 56:819-827. doi:10.1111/j.1365-3059.2007.01647.x.

9. Ezuka, A., Horino, O., Toriyama, K., Shinoda, H., and Morinaka, T. 1975. Inheritance of resistance of rice variety Wase Aikoku 3 to Xanthomonas oryzae. Bull. Tokai Kinki Natl. Agric. Exp. Stn. 28:124-130.

10. Fortune, M. 1990. Bacterial blight and other diseases. Pages 39-44 in: Proc. One-day Workshop on Anthurium Production. Ministry of Food production and Marine Exploitation Research Division, Centeno, Trinidad and Tobago.

11. Fukui, H., Alvarez, A. M., and Fukui, R. 1998. Differential susceptibility of anthurium cultivars to bacterial blight in foliar and systemic infection phases. Plant Dis. 82:800-806.

12. Fukui, R., Fukui, H., and Alvarez, A. M. 1999. Effect of temperature on the incubation period and leaf colonization in bacterial blight of anthurium. Phytopathology 89:1007-1014.

13. Fukui, R., Fukui, H., McElhaney, R., Nelson, S. C., and Alvarez, A. M. 1996. Relationship between symptom development and actual sites of infection in leaves of anthurium inoculated with a bioluminescent strain of Xanthomonas campestris pv. dieffenbachiae. Appl. Environ. Microbiol. 62:1021-1028.

14. Higaki, T., Lichty, J. S., and Moniz, D. 1994. Anthurium culture in Hawaii. HITAHR (Hawaii Inst. Trop. Agric. Human Resources) Res. Ext. Ser. 152.

15. Ignatov, A., Kuginuki, Y., Hida, K., and Taylor, J. D. 2001. Resistance of brassicas with B and D genome to Xanthomonas campestris pv. campestris, causal agent of black rot. J. Russ. Phytopathol. Soc. 2:59-61.
16. Jamwal, R. S., and Sharma, P. P. 1986. Inheritance of resistance to black rot (Xanthomonas campestris pv. campestris) in cauliflower (Brassica oleracea var. Botrytis). Euphytica 35:941-943.

17. Kamemoto, H. 1988. History and development of anthuriums in Hawaii. Pages 4-5 in: Proc. Anthurium Blight Conf., 1st. A. M. Alvarez, ed. HITAHR (Hawaii Inst. Trop. Agric. Human Resources) J. Ser. 02.04.88. University of Hawaii, Manoa, Honolulu.

18. Kamemoto, H., and Kuehnle, A. R. 1996. Breeding anthuriums in Hawaii. University of Hawaii Press, Manoa, Honolulu.

19. Kamemoto, H., Kuehnle, A., Kunisaki, J., Aragaki, M., Higaki, T., and Imamura, J. 1991. Breeding for bacterial blight resistance in anthurium. Pages 39-41 in: Proc. Hawaii Anthurium Ind. Conf., 4th. A. M. Alvarez, D. C. Deardorff, and K. B. Wadsworth, eds. HITAHR (Hawaii Inst. Trop. Agric. Human Resources) J. Ser. 04.06.91. University of Hawaii, Manoa, Honolulu.

20. Kamemoto, H., Kuehnle, A., Kunisaki, J., Aragaki, M., Higaki, T., and Imamura-Lichty, J. 1994. Breeding for new bacterial blight resistant cultivars, a progress report. Pages 39-40 in: Proc. Hawaii Anthurium Ind. Conf., 5th. K. M. Delate and C. H. M. Tome, eds. HITAHR (Hawaii Inst. Trop. Agric. Human Resources) J. Ser. 02.02.94. University of Hawaii, Manoa, Honolulu.

21. Kamemoto, H., Kunisaki, J., Aragaki, M., and Higaki, T. 1986. Evaluation of anthurium accessions. HITAHR (Hawaii Inst. Trop. Agric. Human Resources) Res. Ext. Ser. 069.

22. Kuehnle, A. R., Fujii, T., Chen, F. C., Alvarez, A., Sugii, N., Fukui, R., Aragon, S. L., and Jaynes, J. M. 2004. Peptide biocides for engineering bacterial blight tolerance and susceptibility in cut-flower anthurium. HortScience 39:1327-1331.

23. Manjaya, J. G., and Pawar, S. E. 1999. New genes for resistance to Xanthomonas campestris pv. glycines in soybean (Glycine max (L.) Merr.) and their inheritance. Euphytica 106:205-208.

24. McCulloch, L., and Pirone, P. P. 1939. Bacterial leaf spot of Dieffenbachia. Phytopathology 29:956-962.

25. Nishijima, W. T. 1988. Anthurium blight: An overview. Pages 6-8 in: Proc. Anthurium Blight Conf., 1st. A. M. Alvarez, ed. HITAHR (Hawaii Inst. Trop. Agric. Human Resources) J. Ser. 02.04.88. University of Hawaii, Manoa, Honolulu.

26. Nishijima, W. T., and Fujiyama, D. K. 1985. Bacterial blight of anthurium. University of Hawaii Coop. Ext. Ser., Commodity Fact Sheet AN4:1-3.

27. Norman, D. J., and Alvarez, A. M. 1994. Latent infections of in vitro anthurium caused by Xanthomonas campestris pv. dieffenbachiae. Plant Cell Tiss. Org. 39:55-61.

28. Ogawa, T. 1987. Gene symbols for resistance to bacterial leaf blight. Rice Genet. Newsl. 4:41-43.

29. Sakai, D. S. 1990. The effect of nitrate and ammonium fertilizer on the contents of anthurium guttation fluid. Pages 18-19 in: Proc. Anthurium Blight Conf., 3rd. A. M. Alvarez, ed. HITAHR Journal Series 05.07.90. University of Hawaii, Manoa, Honolulu.

30. Sidhu, G. S., Khush, G. S., and Mew, T. W. 1978. Genetic analysis of bacterial blight resistance in seventy-four cultivars of rice, Oryza sativa $\mathrm{L}$. Theor. Appl. Genet. 53:105-111.

31. Vauterin, L., Hoste, B., Kersters, K., and Swings, J. 1995. Reclassification of Xanthomonas. Int. J. Syst. Bacteriol. 45:472-489.

32. Vicente, J. G., Taylor, J. D., Sharpe, A. G., Parkin, I. A. P., Lydiate, D. J., and King, G. J. 2002. Inheritance of race-specific resistance to Xanthomonas campestris pv. campestris in Brassica genomes. Phytopathology 92:1134-1141.

33. William, P. H., Staub, T., and Sutton, J. C. 1972. Inheritance of resistance in cabbage to black rot. Phytopathology 62:247-252.

34. Young, F. 1990. Anthurium blight in Jamaica. Page 37 in: Proc. Anthurium Blight Conf., 3rd. A. M. Alvarez, ed. HITAHR J. Ser. 05.07.90. University of Hawaii, Manoa, Honolulu. 